\title{
RESEÑA. ENTRE SANTAS, BRUXAS, LOUCAS E FEMMES FATALES
}

\section{REVIEW. ENTRE SANTAS, BRUXAS, LOUCAS E FEMMES FATALES}

\author{
Víctor Amar \\ Universidad de Cádiz \\ https://orcid.org/0000-0001-9036-2651 \\ victor.amar@uca.es
}

Recibido: 03 /03/2020 Revisado: 15/03/2020 Aceptado: 01/04/2020

Autora: Sandra de Souza Machado

Editoria: Appris: Brasil

Año: 2019

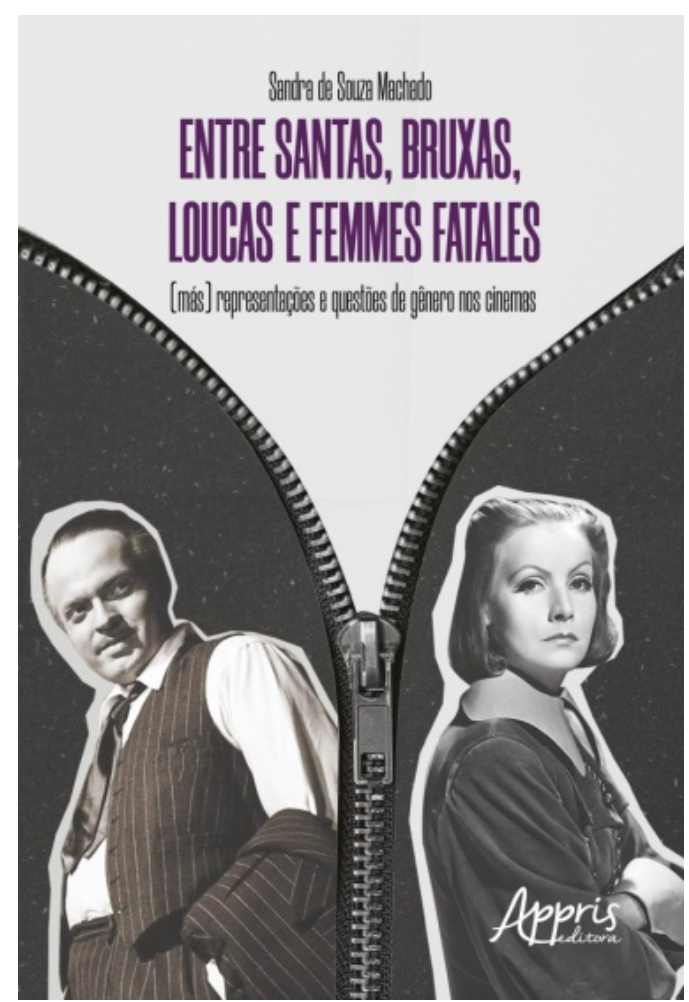

Cómo citar este artículo: Amar, V. (2020) Reseña. "Entre santas, bruxas, loucas e femmes fatales". Hachetetepé. Revista científica en Educación y Comunicación, (20), 115-116.doi: http://doi.org/10.25267/Hachetetepe.2020.i20.16

La lectura de un libro suele ser agradable. Pero imagínense leer cine en papel. Entonces, al placer inicial de la lectura de un libro hay que aunarle el añadido de que sea de cine. Y este es el caso del trabajo realizado por la profesora Sandra de Souza Machado, de la Universidad de Brasilia, titulado "Entre santas, bruxas, loucas e femmes fatales (más) reprentações e questões de gênero nos cinemas", de 2019, publicado en Curitiba (Brasil), con la editora Appris. 
Sinceramente, nos introducimos en un inmenso recorrido por las pantallas abiertas por cremalleras que dejan al descubierto las partes más desacostumbradas de los actores y actrices de cine. Y hacemos alusión a las cremalleras a partir de lo simbólico de la portada del libro que abre la posibilidad de empezar a ver cine, aunque sea en papel.

Con 365 páginas, el libro cubre todos los días del año y todos los cines por ver, tal vez, otra coincidencia simbólica. Con esta visión sobre el cine se incentiva ciertas representaciones y cuestiones de género en el cine (en clara alusión al subtítulo). Se establecen situaciones de aprendizaje, nos ofrecen pautas para saber... Nos dejan con los ojos bien abiertos ante la necesidad de seguir sabiendo.

Lo simbólico nos acerca a lo figurativo o lo imaginario que tiene el cine. Lo que lo hace distintivo y un pretexto para empezar a o continuar bajando la cremallera y alumbrar la pantalla del cine de masas, donde el público es público, pero usted, lector (y no nos olvidamos de la lectora), se convierte en espectador, pues comienza a separar con la mirada. Un cine que en estas páginas no solo se mira sino que se admira. Un cine que hace alusión a películas de producción norteamericana, sudamericana, europeas y del mundo. Todo un lujo que con el pasar de las páginas la esplendorosa pantalla se funde con el negro sobre blanco del libro. Y de nuevo la imaginación del espectador se diluye con lo simbólico...

Aprender de cine es y se hace inevitable con este libro. Dícese de santas y brujas, de locas y mujeres fatales pero no nos lo creemos. Ellas son las protagonistas. Sin ellas no hubiese tenido ese sentido el cine. Lo femenino no es simbólico, se trata de una evidencia. Ellas tienen identidad, son de papel que se proyectan en la pantalla y que el lector las puede imaginar saliendo de sus hojas mientras que el espectador no tiene más remedio que seguirlas a través de la pantalla.

Un libro escrito por una mujer. Un libro que tiene género. Un libro que las mira y un espectador que las admira, o viceversa. Bueno, disculpen, sin olvidarnos de lo simbólico, un espectador embelesado pues la belleza se plasma en las imágenes, mientras el lector la imagina. Y, tal vez, con unos resultados: la mujer representada o la mujer soñada. Ambas son posibles en y con la magia del cine (igualmente en papel). Pero, también, hay cabida para la mujer seducida o perdedora... O, tal vez, por eso son santas, brujas, locas y mujeres fatales. $\mathrm{O}$ ¿es qué todo fue una invención del hombre?

Si fue creada a partir del hombre, tal como algunos mitos clásicos, quedo desprotegida. La mujer tiene mucho de masculino para hacerse mala, para presentarse fuera de lo común (para otros sería de lo normal). Pues el que define los límites sigue siendo el hombre. Y, continuando siéndoles sincero, este libro hacía falta. No es un halago para la escritora o a la editorial brasileña. Lo es por la sencilla razón que conmueve. No le dejará impasible. Se pondrá del lado de ellas. Y no deseará que el "muchachito" de la película venga a salvarla. Ellas son luchadoras, guerreras, lúcidas y mujeres hechas a sí mismas, aunque también víctimas o demandantes de justicia.

Las mujeres se desenvuelven en la pantalla, pero seguro que el espectador después de leer el libro termina pensando en que ellas son las que deberían haber ganado el pulso, dejar al chico antes o bien mirar a otro lado sin ningún tipo de remordimiento.

Viva el cine en papel. Viva lo simbólico y viva la sinceridad con que se trata la temática de género. Hacía falta.

Machado, S. de S. (2019). Entre santas, bruxas, loucas e femmes fatales. Brasil: Appris. 